\title{
ANALYSIS OF DEGRADATION PROCESSES IN RESERVOIRS BASED ON REMOTE SENSING DATA
}

\author{
Joanna Jaskuła ${ }^{\bowtie}$, Mariusz Sojka \\ Faculty of Environmental Engineering and Spatial Management, Poznań University of Life Sciences, ul. Piątkowska 94, \\ 60-649 Poznań
}

\begin{abstract}
Aim of the study

The primary objective was to assess spatio-temporal changes of the vegetation occurring in 12 reservoirs located in the Odra River basin. The analysis was made for reservoirs of different constructions, i.e. single stage, two-stage and lateral. The second purpose was to analyze possibility using remote sensing data to monitor the dynamics of the vegetation processes.
\end{abstract}

\begin{abstract}
Material and methods
Monitoring and mapping of spatio-temporal changes of the vegetation occurring in the reservoirs was analyzed on the basis on Sentinel-2 data. The analysis was based on the NDVI and the WAVI indices. To specify spatial changes of vegetation, the reservoirs were split into zones equals to $250 \mathrm{~m}$. The statistical analysis was aimed at comparing the NDVI and the WAVI values between designated zones. In turn, Cluster analysis (CA) was used to group reservoirs into clusters on the basis of similarities between the NDVI and the WAVI values.

\section{Results and conclusions}

Cluster analysis (CA) showed that each reservoir is separate water body where decisive impact on degradation process could have different factor. There was observed that two-stage construction focuses degradation processes in pre-reservoir and protect water resources in the main part. Additionally, relatively new solution - lateral reservoirs seems to be alternative preventing degradation processes. Taking into account possibility of using satellite imagery, there was observed that resolutions of Sentinel-2 satellite imagery allow to monitor vegetation processes in terms of time and space. The major limitation of using remote sensing data is high cloud density, which significantly reduces the number of observations during most of the year.
\end{abstract}

Keywords: reservoirs, water transparency, Satellite Imagery, Sentinel-2, overgrowth process

\section{INTRODUCTION}

In recent years, climate changes have had substantial impact on water resources (Dąbrowska et al., 2017; Francés et al., 2017; Huang et al., 2015; Song et al., 2014). In order to conduct proper water management and limit the effects of extreme phenomena (droughts, floods), retention reservoirs are being built around the world. Many of them are multifunctional reservoirs whose function is to reduce risk of flood, to store water for agriculture and society, to generate hydropower, and to serve tourism and recreation purposes. Due to the fact that water demand is still increasing, there is continued need to store water of

『e-mail: joanna.jaskula@up.poznan.pl 
good quality (Wang et al., 2019). In recent years, the problems related to the functioning of reservoirs were highlighted in many studies (Dąbrowska et al., 2016; Sojka et al., 2017). One of the most serious problems related to the functioning of reservoirs is the change in water quality and transparency, affected by concentration of algae blooms, chlorophyll and suspended sediments. Additionally, the ongoing overgrowth process can lead to gradual decrease and disappearance of water bodies. In order to limit the impact of degradation processes in reservoirs, approaches to planning and structures of reservoirs were changed over past years. The most popular are dam reservoirs, structured as single water bodies, where dam is located in river valley. Previous studies have shown that such reservoir structure is exposed to many negative phenomena, e.g. sedimentation and degradation of water quality (Khorrami and Barihashemi 2019, Noori et al. 2018, Tadesse and Dai 2019). One of the most promising solutions seems to be two-stage reservoirs with a separated preliminary part. According to Wicher-Dysarz (2019) and Sojka et al. (2018), the structure of the two-stage reservoirs has impact on the reduction of sediments and biogenic compounds which inflow into the main part. Another technical solution, which has been applied more frequently in the last years, is the structure of lateral reservoirs. The lateral reservoirs have slight impact on hydrological regime of rivers, and they are less prone to sediment accumulation due to their location outside the riverbed (Przybyła et al., 2015).

The state of the reservoirs is a dynamic process, which is strictly connected with environmental changes. Monitoring of the processes occurring in reservoirs needs regular and continuous data storing. Traditional monitoring of water bodies is based on in situ measurements (Bogdał et al., 2015; Gao et al., 2016). Unfortunately, this method provides information limited to point-based representation and does not give a spatial overview of the reservoir's condition. Currently, remote-sensing techniques have a unique advantage in monitoring and mapping seasonal dynamics of processes in reservoirs from space (Klein et al., 2017; Martins et al., 2019; Pekel et al., 2016). Satellite imagery has numerous operational and economic advantages compared to in situ measurements. Currently, cost-free satellite imagery is provided from Landsat, MERIS/OLCI, MODIS and Sentinel satellites (Beck et al., 2017). Additionally, satellite imagery enables detection of spatial-temporal changes in the environment by repeat coverage of satellite sensors. Monitoring of vegetation dynamics is mainly based on vegetation indices (VIs). The relationship between in situ data and VIs has been described and confirmed in many studies (Dörnhöfer et al., 2018; Silva et al., 2016; Yadav et al., 2017). Due to the fact that values of spectral indices provide current information about surface area, they are widely used for environmental, agricultural, economic and security purposes.

The aim of this paper was to analyse the degradation processes in the reservoirs located in the Odra River basin, based on remote sensing data. The analysis was made for selected reservoirs of different structures, i.e. single stage reservoirs (Jeziorsko, Jeżewo, Przebędowo, Rydzyna, Słupca, Środa, Września), twostage reservoirs (Jezioro Kowalskie, Radzyny, Stare Miasto) and lateral reservoirs (Jutrosin, Pakosław).

\section{STUDY AREA}

The analysis of degradation processes was carried out for 12 reservoirs located in the Odra River basin (see: Fig. 1). Most of them are located in the Warta River basin (except Jeżewo, Jutrosin, Pakosław and Rydzyna reservoirs). The reservoirs were built in the years 1955-2014, and they are characterized by different technical and structural parameters. Most of them are classic single stage reservoirs, three have a two-stage structure, and further two are lateral facilities (see: Table 1).

The size of the reservoirs ranges from 12 ha (Przebędowo) to 3694 ha (Jeziorsko), while their capacities range from 0.162 (Przebędowo) to $143 \mathrm{mln} \mathrm{m}^{3}$ (Jeziorsko). The total area of the analysed reservoirs equals 4662.37 ha, while the total capacity is more than $161 \mathrm{mln} \mathrm{m}^{3}$. Mean depth varies from 0.9 to $4.5 \mathrm{~m}$, and the length of the shoreline is within the range of $2.15-46.63 \mathrm{~km}$ (see: Table 1). The reservoirs are multi-purpose facilities, and the water stored therein is mainly used for agricultural purposes. Additional functions are flood wave reduction, hydropower generation (Jeziorsko, Stare Miasto) and recreation. Over the last decades, the problems related to reservoirs' 


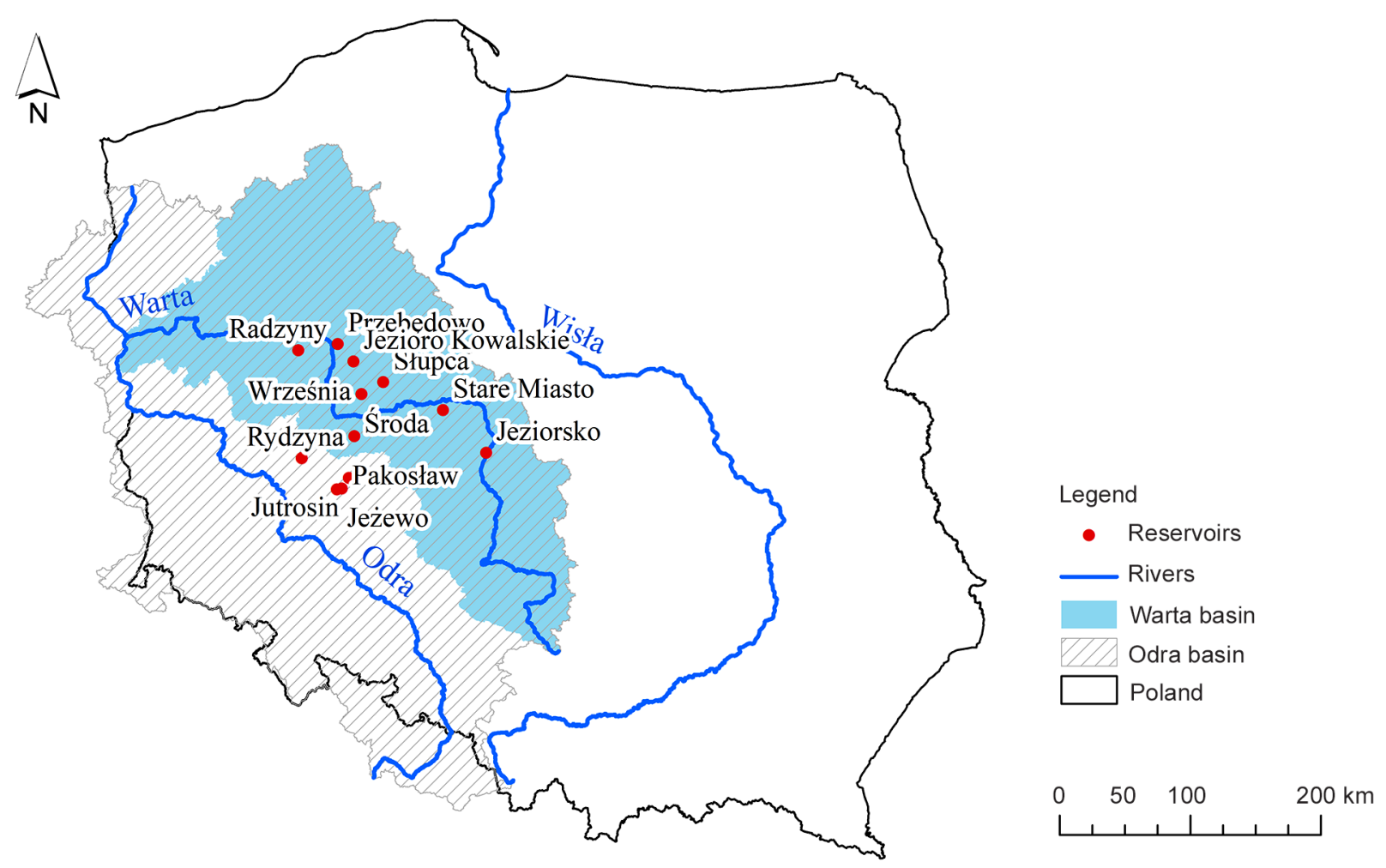

Fig. 1. Study site location

functioning have been observed, which is especially related to degradation processes such as sediment accumulation, changes in water quality, seasonal algae bloom and progressing overgrowth.

\section{MATERIAL AND METHODS}

Monitoring and mapping of seasonal spatial-temporal changes occurring in reservoirs was analysed on the basis on Sentinel-2 satellite data. Satellite imagery was acquired from the Copernicus Open Access Hub European Space Agencies (https://scihub.copernicus.eu/). The Sentinel-2 constellation is part of the Copernicus Earth observation mission, previously known as Global Monitoring for Environment and Security (GMES) program. The Sentinel-2A was launched on 23rd June 2015, while the Sentinel-2B started on 7th March 2017. The main sensor of the satellite, Multi-Spectral Imager (MSI), provides data from 2-3 day (at mid latitudes) to 5-day repeat cycle (at the Equator). The MSI instrument features 13 spectral bands from visible, near-infrared (VNIR) to short-wave infrared (SWIR) radiation in 10, 20 and $60 \mathrm{~m}$ spatial resolution, depending on the band.

Satellite data selected for the analysis was provided in Level-1C product, which includes radiometric (Top of Atmosphere - TOA) and geometric (sub-pixel registration) correction, including orthorectification and spatial assignment to a global reference system (WGS84, EPSG:4326). Finally, a total of 18 Sentinel-2 images from May, June, July, August, September and October 2018 were collected for further analysis (granules: UCC, UXT, UXU, UYT). In the pre-processing stage, all bands were resampled to $10 \mathrm{~m}$ spatial resolution on the basis of red band (B4) in Sentinel Application Platform (SNAP). Next, resampled images were clipped with the reservoir's vector masks. The analysis of reservoir degradation processes was based on Normalized Difference Vegetation Index (NDVI) and Water Adjusted Vegetation Index (WAVI), which were calculated for each satellite image. The spectral indices were calculated using Band Maths tool in SNAP. 
Table 1. Basic parameters of the analyzed reservoirs

\begin{tabular}{|c|c|c|c|c|c|c|c|c|}
\hline Reservoir & River & Construction & Year & $\begin{array}{l}\text { Area } \\
{[\text { ha }]}\end{array}$ & $\begin{array}{l}\text { Capacity } \\
{\left[\mathrm{mln}^{3}\right]}\end{array}$ & $\begin{array}{l}\text { Mean } \\
\text { depth } \\
{[\mathrm{m}]}\end{array}$ & $\begin{array}{l}\text { Perimeter } \\
{[\mathrm{km}]}\end{array}$ & Functioning problems \\
\hline $\begin{array}{l}\text { Jezioro } \\
\text { Kowalskie }\end{array}$ & Główna & $\begin{array}{l}\text { two-stage } \\
\text { reservoir }\end{array}$ & 1984 & 203.0 & 6.58 & 3.68 & 18.63 & $\begin{array}{l}\text { algae bloom, overgrowth process, } \\
\text { poor water quality }\end{array}$ \\
\hline Jeziorsko & Warta & $\begin{array}{l}\text { single stage } \\
\text { reservoir }\end{array}$ & 1986 & 3694.0 & 143.0 & 4.5 & 46.63 & $\begin{array}{l}\text { algae bloom, overgrowth process, } \\
\text { reservoir management, sediment } \\
\text { accumulation }\end{array}$ \\
\hline Jeżewo & Pogona & $\begin{array}{l}\text { single stage } \\
\text { reservoir }\end{array}$ & 2003 & 65.52 & 2.10 & 2.3 & 8.38 & $\begin{array}{l}\text { algae bloom, overgrowth process, } \\
\text { poor water quality }\end{array}$ \\
\hline Jutrosin & Orla & $\begin{array}{l}\text { lateral } \\
\text { reservoir }\end{array}$ & 2011 & 90.50 & 1.90 & 2.1 & 5.59 & $\begin{array}{l}\text { algae bloom, overgrowth process, } \\
\text { poor water quality, reservoir } \\
\text { management }\end{array}$ \\
\hline Pakosław & Orla & $\begin{array}{l}\text { lateral } \\
\text { reservoir }\end{array}$ & 2006 & 26.60 & 0.33 & 1.3 & 2.15 & $\begin{array}{l}\text { algae bloom, overgrowth process, } \\
\text { reservoir management, sediment } \\
\text { accumulation }\end{array}$ \\
\hline Przebędowo & Trojanka & $\begin{array}{l}\text { single stage } \\
\text { reservoir }\end{array}$ & 2014 & 12.03 & 0.162 & 0.94 & 2.94 & $\begin{array}{l}\text { overgrowth process, poor water } \\
\text { quality, }\end{array}$ \\
\hline Radzyny & Sama & $\begin{array}{l}\text { two-stage } \\
\text { reservoir }\end{array}$ & 2001 & 109.44 & 2.88 & 1.6 & 11.47 & $\begin{array}{l}\text { algae bloom, dam subsidence, dam } \\
\text { movement, low inflow to reservoir, } \\
\text { overgrowth process, reservoir } \\
\text { management, sediment accumulation }\end{array}$ \\
\hline Rydzyna & $\begin{array}{l}\text { Rów } \\
\text { Dąbiecki }\end{array}$ & $\begin{array}{l}\text { single stage } \\
\text { reservoir }\end{array}$ & 2013 & 40.60 & 0.757 & 1.9 & 3.57 & $\begin{array}{l}\text { algae bloom, low inflow to reservoir, } \\
\text { poor water quality }\end{array}$ \\
\hline Słupca & Meszna & $\begin{array}{l}\text { single stage } \\
\text { reservoir }\end{array}$ & 1955 & 258.0 & 0.46 & 2.1 & 9.25 & $\begin{array}{l}\text { algae bloom, overgrowth process, } \\
\text { poor water quality }\end{array}$ \\
\hline Stare Miasto & Powa & $\begin{array}{l}\text { two-stage } \\
\text { reservoir }\end{array}$ & 2006 & 90.68 & 2.159 & 2.4 & 8.24 & $\begin{array}{l}\text { algae bloom, dam movement, } \\
\text { construction errors of the fish pass } \\
\text { and hydropower, low inflow to } \\
\text { the reservoir, overgrowth process, } \\
\text { reservoir management, sediment } \\
\text { accumulation }\end{array}$ \\
\hline Środa & Maskawa & $\begin{array}{l}\text { single stage } \\
\text { reservoir }\end{array}$ & 1971 & 39.00 & 0.90 & 2.3 & 6.03 & $\begin{array}{l}\text { algae bloom, overgrowth process, } \\
\text { poor water quality }\end{array}$ \\
\hline Września & Wrześnica & $\begin{array}{l}\text { single stage } \\
\text { reservoir }\end{array}$ & 1967 & 33.00 & 0.30 & 0.9 & 5.85 & $\begin{array}{l}\text { algae bloom, overgrowth process, } \\
\text { poor water quality }\end{array}$ \\
\hline
\end{tabular}

During recent decades it was shown in many studies that the NDVI is used to indicate the vegetation areas in land and water environments (Wen et al., 2017; Xiao et al., 2019; Zhu et al., 2015). The NDVI index is based on a combination of $\operatorname{NIR}\left(\rho_{N I R}\right)$ and red $\left(\rho_{R}\right)$ bands:

$$
\mathrm{NDVI}=\frac{\rho_{N I R}-\rho_{R}}{\rho_{N I R}+\rho_{R}}
$$

The WAVI spectral index was developed by Villa et al. (2014) for monitoring and mapping aquatic vegetation and transitional ecosystems. Previous studies have confirmed that the WAVI shows enhanced capabilities in overgrowth process detection (emergent and floating plants), compared to pre-existing indices (Sojka et al., 2019; Hestir et al., 2014). The WAVI is a combination of background signal $(L=0.5)$, NIR $\left(\rho_{N I R}\right)$ and blue $\left(\rho_{B}\right)$ bands: 


$$
\mathrm{WAVI}=(1+L) \frac{\rho_{N I R}-\rho_{B}}{\rho_{N I R}+\rho_{B}+L}
$$

In the next step, the subsets of the NDVI and WAVI bands were created for each reservoir and exported to GIS software.

To specify areas mainly covered by vegetation depending on the distance from the river inflow, the reservoirs were split into zones. The distance between profiles splitting the zones equals $250 \mathrm{~m}$, except twostage reservoirs where zones located pre-dam were split.

Finally, in order to assess seasonal spatial-temporal dynamics of the vegetation process, values of NDVI and WAVI for each satellite image were extracted to point layer. According to information from the Sentinel Hub website (https://www.sentinel-hub.com), the values of vegetation indices vary from -1 to +1 , where low values (negative or approaching zero) represent water, soil and rocks, while higher values represent vegetation - in aquatic environment there are seasonal algal blooms, emergent and floating plants. According to previous studies (Jaskuła et al., 2018), the NDVI values higher than 0.2 were detected in low water transparency areas (caused by algae blooms), while the values above 0.6 may indicate areas of algae blooms (in high concentrations) or overgrowth by emergent plants. The WAVI values higher than 0.2 may be used for detecting areas overgrown with emergent and floating plants. All calculations on the

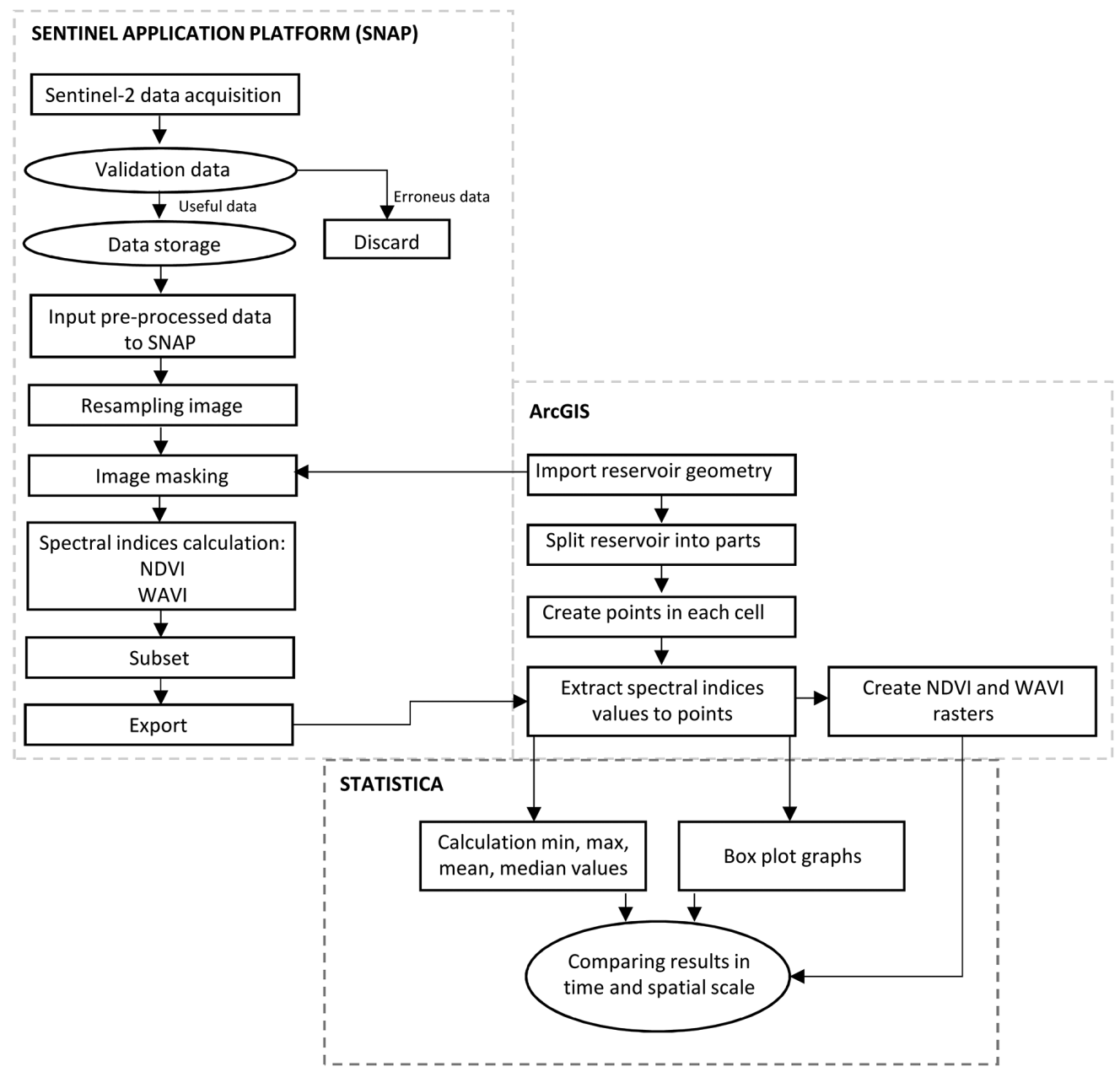

Fig. 2. Methodology applied in this study 
basis of satellite imagery were performed with Sentinel Application Platform (SNAP) and ArcGIS 10.6 software. Figures presenting seasonal spatial-temporal changes of vegetation indices values were created for characteristic months - May (mean values), August (maximum values) and October (minimum values). The statistical analysis was aimed at comparing the NDVI and WAVI values between parts of the reservoir designated for this study. Cluster analysis (CA) was used to group reservoirs into clusters on the basis of similarities between NDVI and WAVI values. The division into groups was made on the spectral indices' values for each month in 13 percentiles $(1,5,10,20$, $30,40,50,60,70,80,90,95$ and 99). As a measure of similarity, the Ward's method with squared Euclidean distances was used. The results of a CA were presented as a dendrogram using the standardized linkage distance $\left(D_{\text {link }} \cdot D_{\max }^{-1}\right) \cdot 100$. Statistical analysis was conducted using Statistica 13 software.

\section{RESULTS AND DISCUSSION}

\section{Single stage reservoirs}

Seasonal spatial-temporal changes of the NDVI and WAVI in a sample single stage reservoir were presented in the Figure 3. For analyzed months, the values of the NDVI were in range $-0.239-0.853$ for the Środa reservoir. During the analyzed period, the highest values were observed in the inlet zone and near the banks of the reservoir, while the lowest values occur near the dam (see: Fig. 3). The highest values of the NDVI occur near the inlet where the low water transparency connected with algae blooms and emergent plants were detected. The WAVI values varied from -0.022 to 0.640 . Similarly to the NDVI, the maximum values occur near the banks of the reservoir, while the lowest are recorded next to dam. It was observed that NDVI and WAVI values were the highest in August during the vegetation season, and the lowest in October.

The analysis of NDVI and WAVI across the reservoirs showed that for most of single stage reservoirs, the highest values occur in the inlet of the river (see: Fig. 4). This area is characterized by the lowest depth, which has positive impact on vegetation development. Additionally, input of biogenic compounds by the rivers which inflow into the reservoir is mainly accumulated in this particular section. The lowest val-
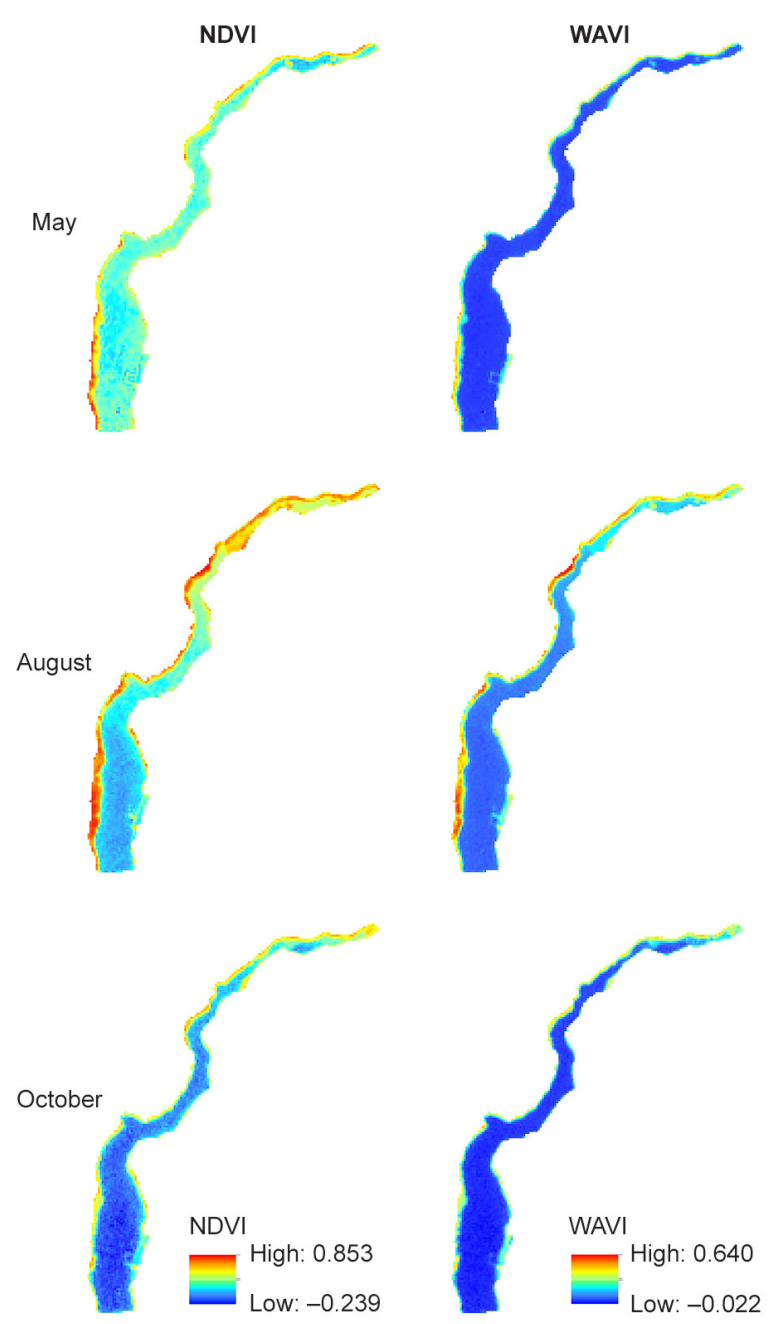

$0.250 .5,1 \mathrm{~km}$

Fig. 3. Spatio-temporal changes of the NDVI and the WAVI values in the Środa reservoir

ues occur in the outlet of the reservoir. Additionally, we have observed that range of values - that is the difference between minimum and maximum - was higher in inlet zones. It means that in these zones, the most pronounced changes in the reservoir occur, caused by degradation processes. However, in the relatively new object (Rydzyna) we have observed that the values of the spectral indices are lower. Across the Rydzyna reservoir, the values remain on a similar level, with the highest values recorded in the outlet zone (see: Fig. 4). 

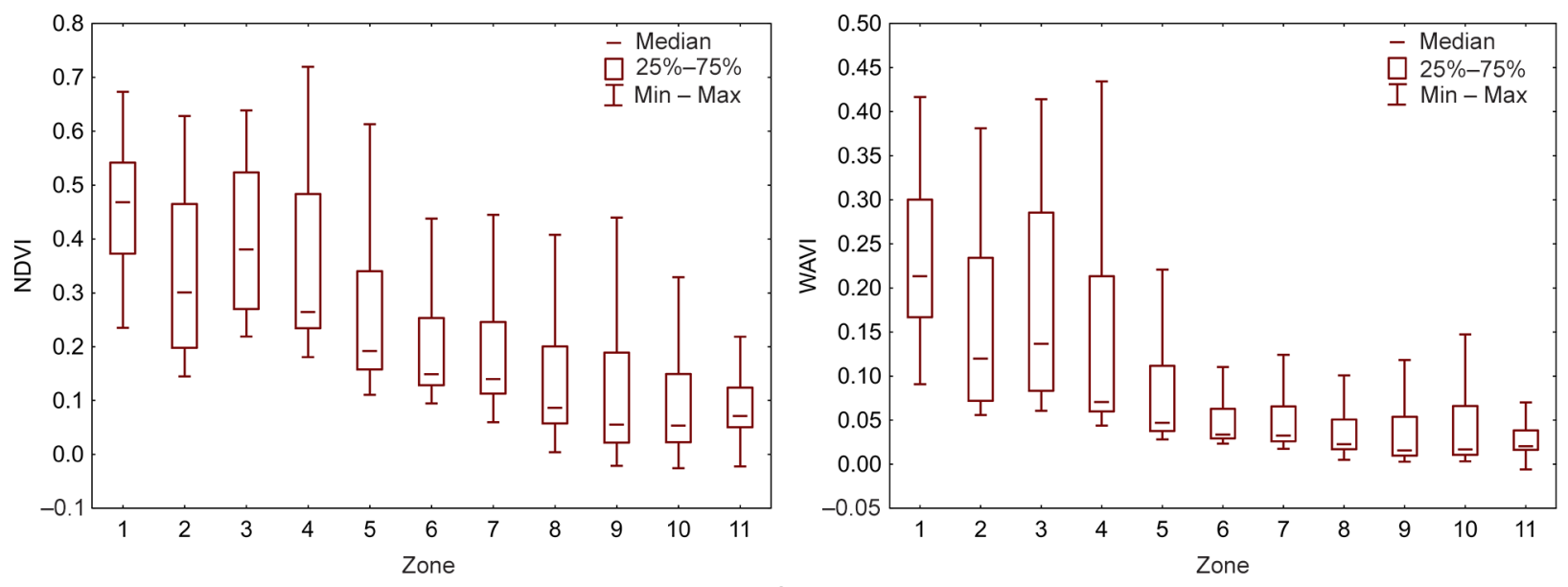

Środa
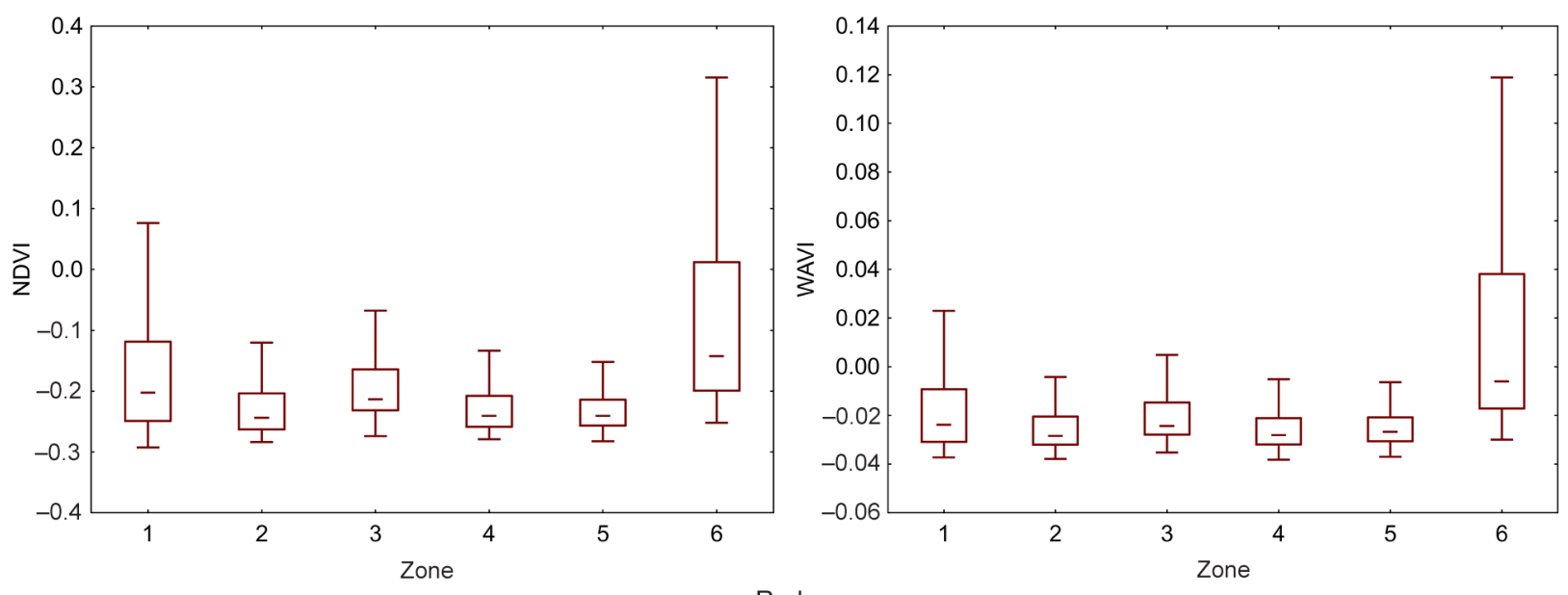

Rydzyna

Fig. 4. Changes of the NDVI and the WAVI mean values along the Sroda and the Rydzyna reservoir

\section{Two-stage reservoirs}

Changes of NDVI and WAVI values in a two-stage reservoir were presented in the Figure 5. The NDVI remained in the range of $-0.552-0.897$ while the WAVI varied from -0.062 to 0.668 . Similarly to single stage reservoirs, the highest values of the WAVI were observed near the banks of the reservoir. The spatial variability of the NDVI shows the dynamics of water transparency changes caused by algae blooms. This process in two-stage reservoir is mainly focused in the pre-reservoir zone. The NDVI values observed in the period from May to October in the pre-reservoir zone were higher than those observed in the main part. The highest values were observed in pre-reservoir in
August. The lowest values were recorded in the main part, in May and October. The highest values of the NDVI in the main part occurred near the banks, where the overgrowth areas of emergent plants were detected. The main part of the reservoir is mainly characterized by low values of the NDVI (approximate to 0), which represent water.

The analysis of degradation process along two-stage reservoir was divided into pre-reservoir (zones 1-8) and main part (zones 9-26). The highest variation of the NDVI and WAVI in the Jezioro Kowalskie were observed within the pre-reservoir, where mean values varied from -0.09 to 0.81 , and from 0.0 to 0.59 , respectively (see: Fig. 6.). The highest NDVI and WAVI values 

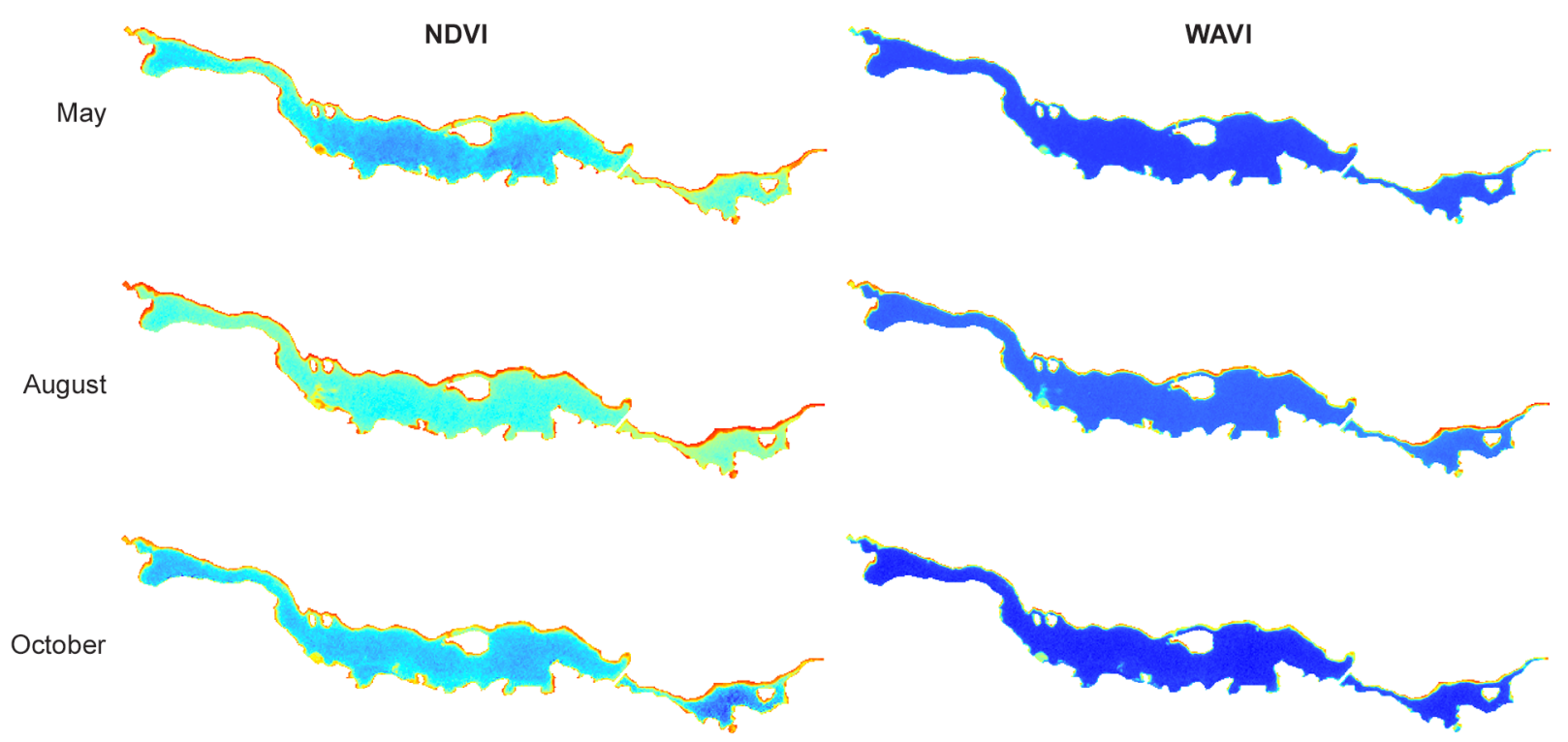

NDVI

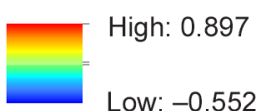

WAVI
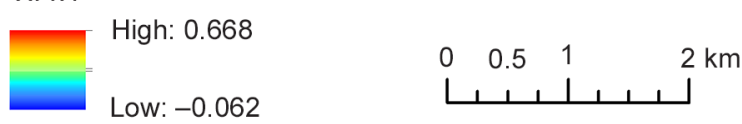

Fig. 5. Spatio-temporal changes of the NDVI and the WAVI values in the Jezioro Kowalskie reservoir

occurred in zone 1 , which is the inlet zone of the reservoir. The lowest values occurred in zones located in main part. The values of the NDVI and WAVI show that the main part of the reservoir is characterized by higher stability. The highest variability in the main part of the Jezioro Kowalskie occurred in zone 19, which is located near the island where overgrowth areas where detected.

Similar conclusions can be formulated for the Radzyny reservoir, where dynamics of degradation processes was observed mainly in the pre-dam part (zones 1-9). The values of the NDVI varied from -0.15 to 0.77 , while the WAVI was in range -0.03 -0.49 (see: Fig. 6). In the main part, the values of spectral indices in each zone were at a similar level. In case of the Stare Miasto reservoir, the values in the pre-reservoir and in the main part have the same range of variation. Slightly higher values were recorded only in the inlet of the reservoir characterized by lower depths. Similar observations in both parts of the Stare Miasto reservoir may be caused by technical operations aimed at cleaning the bottom of the reservoir from stored sediments and pollution in 2017.
The analysis of changes in NDVI and WAVI values across two-stage reservoirs (Jezioro Kowalskie, Radzyny) showed that the highest variation occurs in the pre-dam part. This confirms the effectiveness of such type of structural solutions in storing sediments and in protecting water resources against degradation caused by algae blooms.

\section{Lateral reservoirs}

Despite the 5-day temporal resolution of Sentinel-2 satellite data, all the available imagery in October was burdened with high cloud cover, and therefore it was not possible to calculate spectral indices used in this study. Due to the lack of data for the month of October, which was selected for further analysis as the month characterized by the lowest values of the NDVI and WAVI, the seasonal spatial-temporal changes in lateral reservoirs were analyzed on the basis of satellite data from May, August and September 2018.

Similarly to single and two-stage reservoirs, the highest values of the NDVI and WAVI were observed 

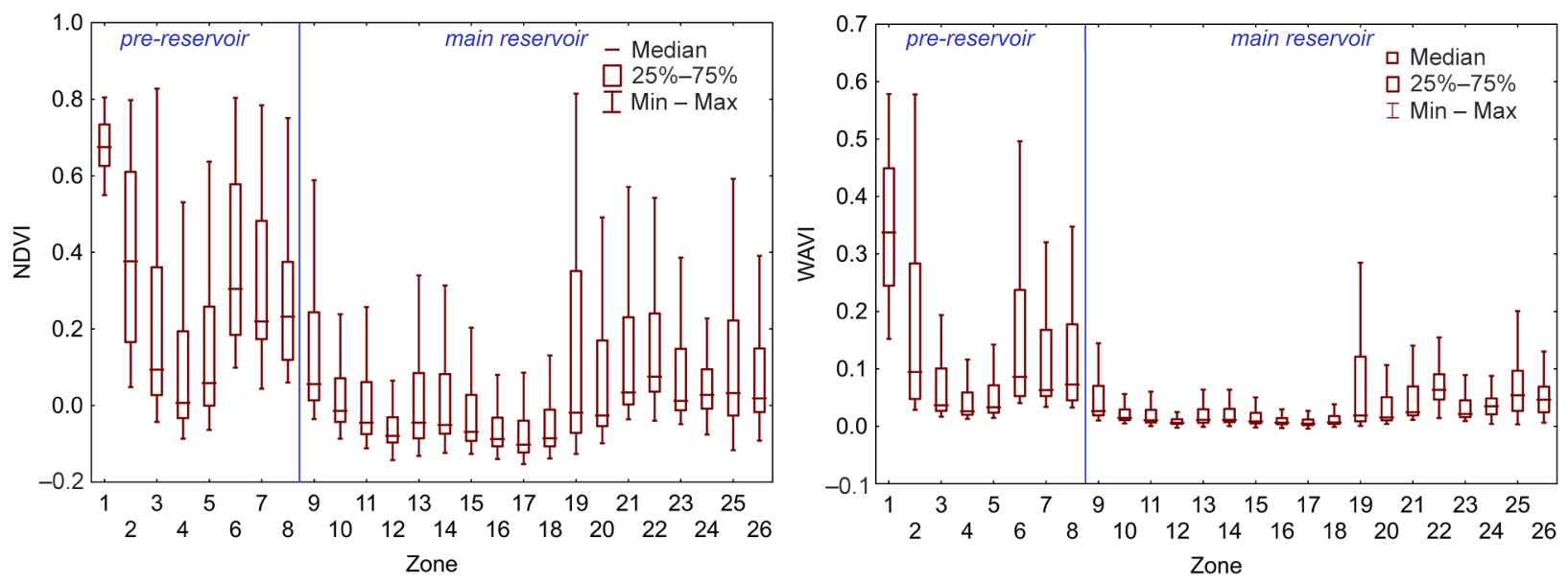

Jezioro Kowalskie
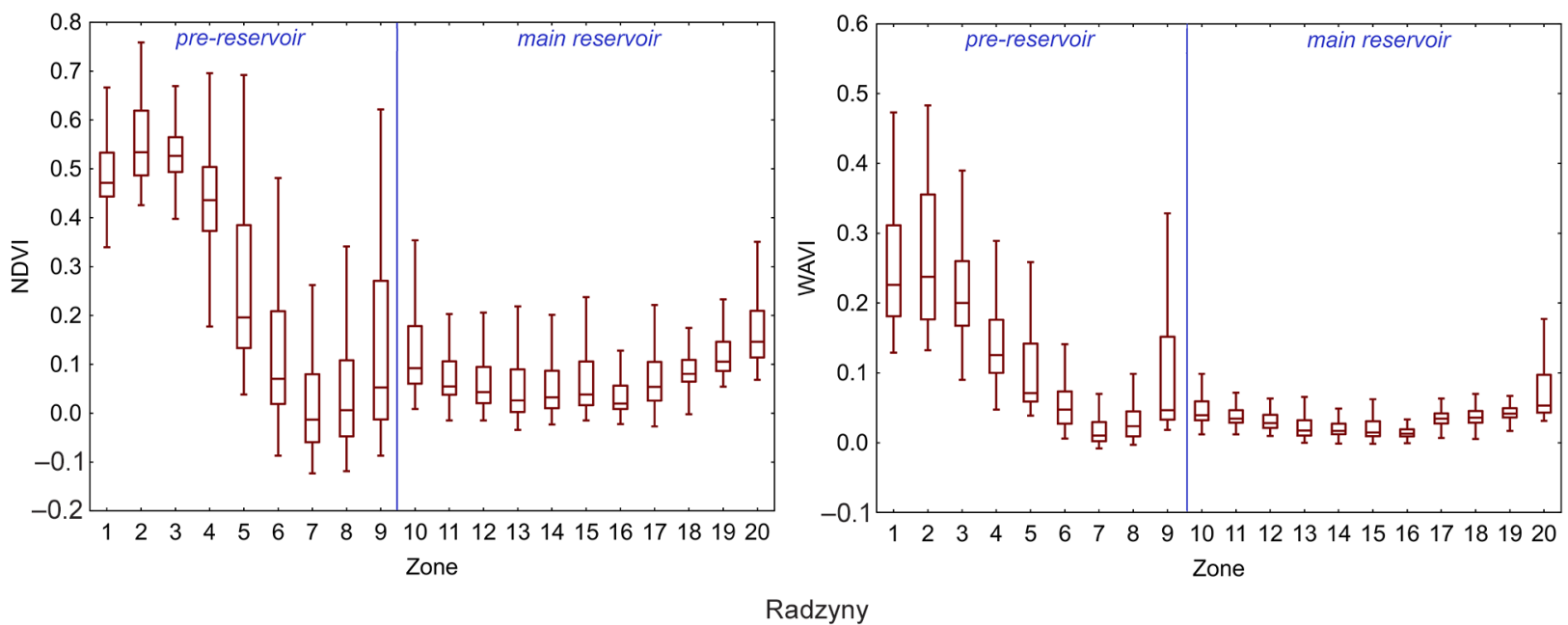

Fig. 6. Changes of the NDVI and the WAVI mean values along the Jezioro Kowalskie and the Radzyny reservoir

near the banks of the reservoir and in the inlet zone. Additionally, high WAVI values were observed in the area of Jutrosin reservoir, located between the bank and an island, which may be caused by small depths and low flows in this part of the reservoir (see: Fig. 7). The NDVI varied from -0.306 to 0.814 while the WAVI values remained in the range $-0.083-0.578$. It was observed that the NDVI and WAVI values were the highest in August during the vegetation season, while they were the lowest in May. Area near the dam and the middle part of the Jutrosin reservoir produced the lowest values from May to September.

The analysis of the mean NDVI values showed similar variability along the Justrosin reservoir. Maxi- mum WAVI values occur in zone 1 , which also demonstrated the highest variability. This may be caused by small depths in the inlet zone and problems with water management in the reservoir (maintenance of normal water level during low flows). Despite only few years' functioning, the small depths, low flows and the accumulation of sediments caused intensive overgrowth process in this part of a relatively new reservoir. Values of the WAVI in other zones were at a similar level (see: Fig. 8). In case of the Pakosław reservoir, the values of spectral indices across whole reservoir have shown a similar level. Slightly lower values and range of variation were recorded in the main part of the reservoir. 

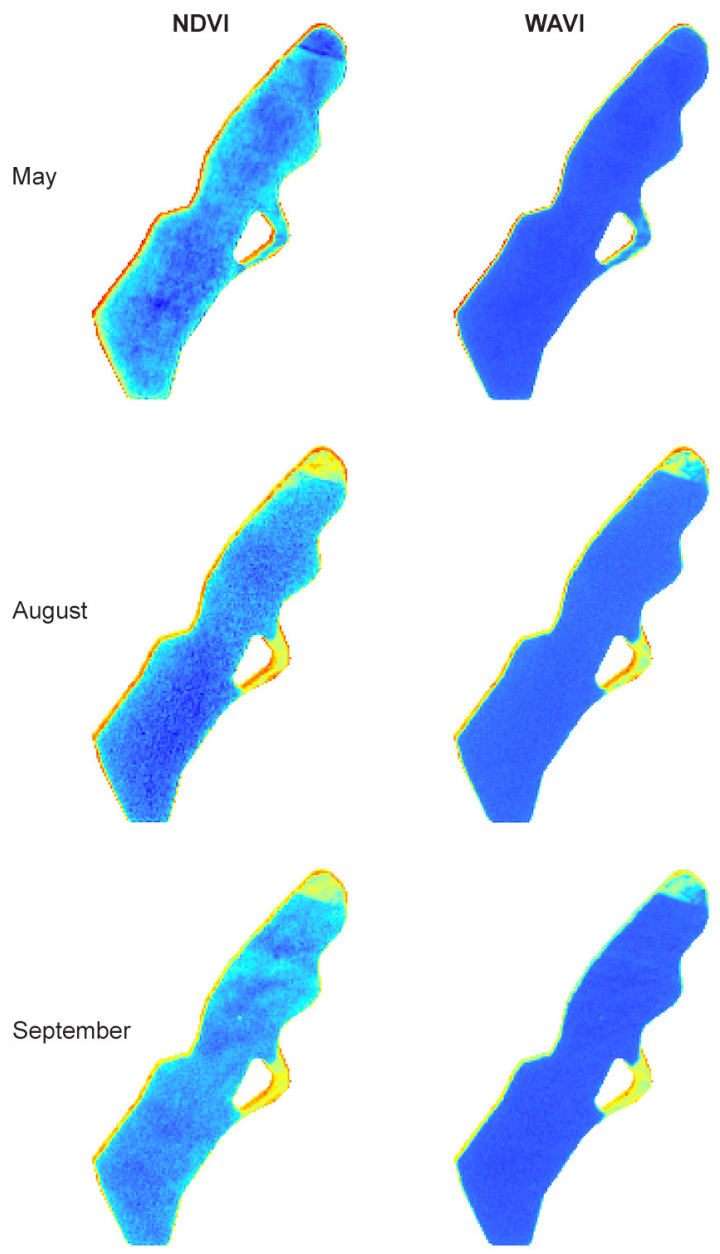

NDVI
Low: -0.306

WAV

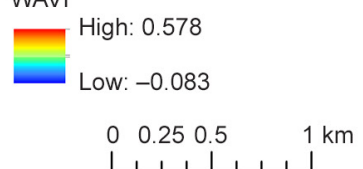

Fig. 7. Spatio-temporal changes of the NDVI and the WAVI values in the Jutrosin reservoir

\section{Overall results}

Cluster analysis (CA) of the NDVI and WAVI values were presented in the Figure 9. The obtained results facilitated grouping the reservoirs into two main groups (Group 1 and Group 2). Additionally, Group 2 was divided in three subgroups. Group 1 contains three reservoirs in which the spectral indices' values were the highest (NDVI - Jeżewo, pre-part in the Radzyny and the Przebędowo reservoirs, WAVI - Jeżewo, Prze- będowo and Września). This group mainly consisted of single stage reservoirs (except the Radzyny reservoir), characterized by a similar longitudinal shape. Group 2, subdivided into three groups, contains reservoirs characterized by different areas, capacity, mean depth and years of functioning (see: Table 1). Grouping together the reservoirs with different characteristics may indicate that degradation processes are intensified by complex factors (structure type, reservoir management, pollution inflow, type of inlet river, land use and slope of basin, surface runoff, thermal conditions). Each of the reservoirs is a separate water body, and in each of those it could be a different factor that has a decisive impact on degradation process. Additionally, we have observed that both parts of the Stare Miasto reservoir are in the same group for each spectral index (NDVI - Group 2-1, WAVI - Group 2-2). Regardless of its two-stage structure, the NDVI and WAVI values are on similar level in the two parts - the pre-reservoir and the main part. This may have been caused by technical works consisting in cleaning the bottom of the pre-reservoir in 2017. After the sediments and the pollution have been removed, the pre-reservoir works as single stage reservoir, where biogenic compounds are stored for only one year. The subgroup 2-3 is characterized by the lowest NDVI and WAVI values. It contains relatively new objects (Jutrosin, Pakosław, Rydzyna) located in close proximity to each other, with similar basin characteristics. Additionally, the Jutrosin and the Pakosław are lateral reservoirs, which due to low spectral values seems to be an alternative structural solution, preventing degradation processes.

Water bodies are among the most altered and damaged environments, and degradation processes in these objects have been observed in many locations around the world. Despite numerous studies concerning eutrophication, algae blooms and overgrowing, there is still no knowledge as to which factor determines degradation the most. It may be determined by geographical location (González-Márquez et al., 2018), natural processes (Liu et al., 2019), hydro-meteorological conditions (Souza et al. 2018), land use and state of wastewater management in the basin (Tang et al., 2019), sediments deposition (Fuska et al., 2017), or water quality in rivers inflowing to the reservoirs (Yu et al., 2019). On the basis of the cluster analysis 

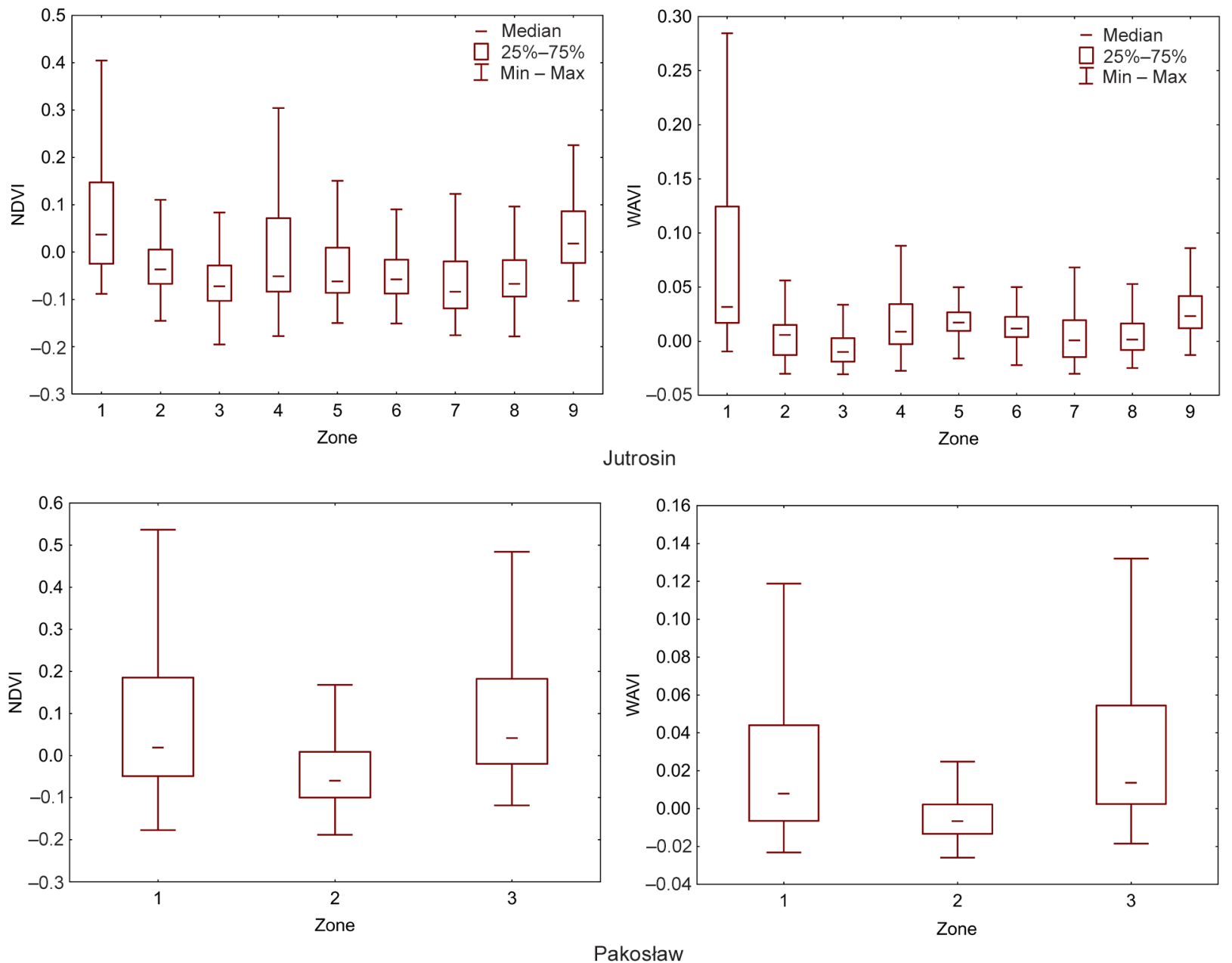

Fig. 8. Changes of the NDVI and the WAVI mean values along the Jutrosin and the Pakosław reservoir

(CA), it was confirmed that multi-factors affecting the increased concentration of algae blooms or changes of overgrowth areas are different in each water body. Regardless of the structural type, the results obtained in different zones showed that the changes of water transparency occur mainly near the inlet where depths are smaller, while the overgrowth areas occur near the reservoir's banks. Additionally, it was observed that two-stage reservoirs (Jezioro Kowalskie, Radzyny) have positive impact on water transparency in the main part, whereas changes in water transparency were observed in pre-reservoir.

Recently, remote sensing techniques show the most valuable opportunities in aquatic monitoring in spatial-temporal scale. Previous studies (Jaskuła et al., 2019, Sojka et al., 2019) have demonstrated that spatial and spectral resolution of the Sentinel-2 satellite makes it possible to detect the changes occurring in the reservoirs. It was confirmed in this study, that the NDVI provides information about the changes of water transparency, while the WAVI facilitates the detection of overgrowth areas. Monitoring of the changes occurring in the aquatic environment needs full, regular and comparable data. Recently, free remote sensing data used for environmental monitoring are provided from Landsat, MERIS/OLCI, MODIS and Sentinel-2 satellites (Beck et al., 2017). In comparison with other non-cost satellites, the Sentinel-2 provides imagery 

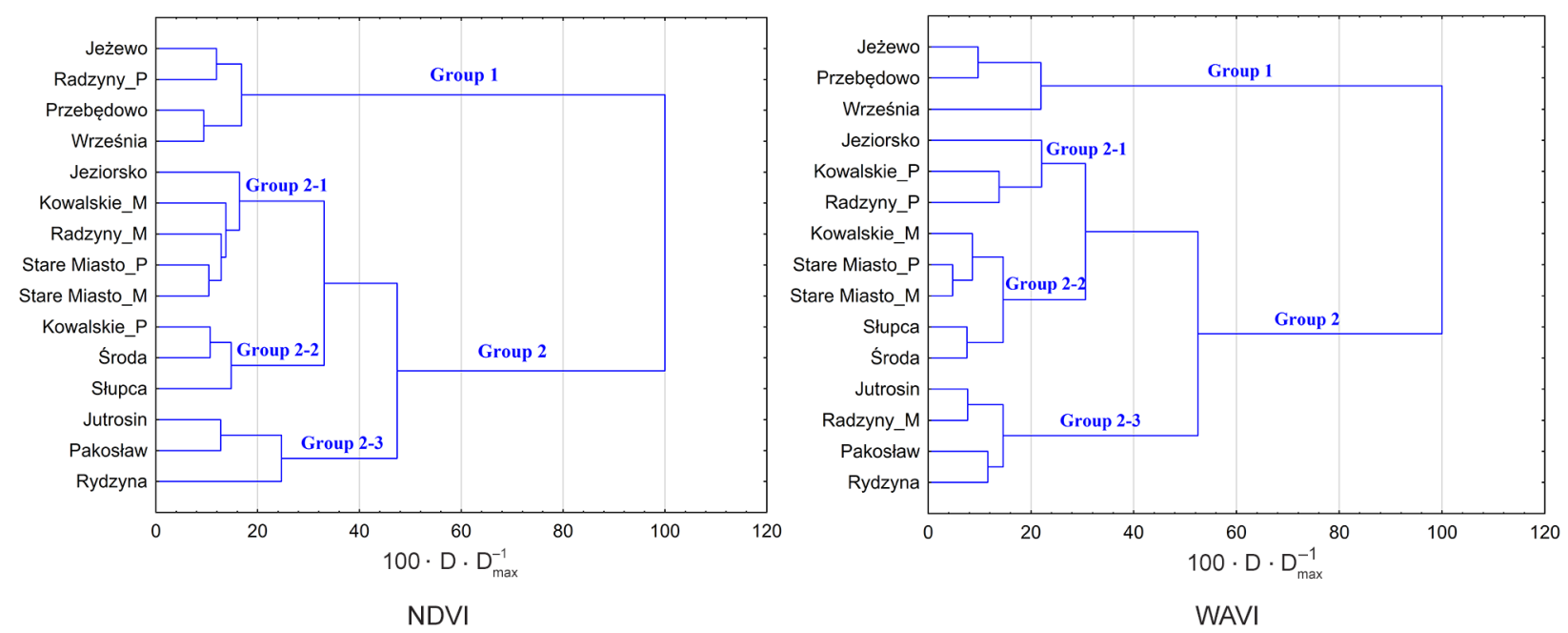

Fig. 9. Cluster analysis of the NDVI and the WAVI values for reservoirs (P- pre-reservoir, $\mathrm{M}$ - main part of two-stage reservoirs)

with unprecedented temporal resolution, and therefore facilitates detecting the dynamics of the processes within 5 days. The major limitation of using Sentinel-2 is high cloud density during data acquisition from the Earth by MSI sensor, which significantly reduces the number of observations. The problem with cloud coverage is particularly challenging for storing remote sensing data, especially in terms of the computation of spectral indices. The studies on cloud coverage have been conducted for Landsat satellite (Alvarez-Mendoza et al., 2019), but there is still no sufficient methodology for Sentinel-2 so far. The development of the solutions concerning cloud density allows for continuous data storing, which is undeniably significant for monitoring degradation processes in reservoirs.

\section{CONCLUSIONS}

The analyses presented in this study allow an assessment of seasonal spatial-temporal changes occurring in reservoirs, using the NDVI and WAVI index. On the basis of the obtained results, the following conclusions can be made:

1. Cluster analysis indicates that each reservoir is a separate water body where different factors might have a decisive impact on the degradation process (including structure type, reservoir management, pollution inflow, type of inlet river, land use and slope of basin, surface runoff, or thermal conditions).

2. Structure of the reservoir has an impact on the spatial distribution of degradation processes (especially, on the changes of water transparency). Analysis of two-stage structure confirms the effectiveness of the pre-dam part in the protection of the main reservoir. The functioning of a relatively new solution - lateral reservoirs - to date seems to be alternative, preventing degradation processes.

3. Seasonal spatial-temporal changes in reservoirs caused by algae blooms and overgrowing are dynamic processes, and to study them, regular and continuous data storing is required. Spatial, temporal and spectral characteristics of Sentinel-2 satellite imagery allow for the monitoring of the vegetation processes in terms of time and space.

4. Spectral indices based on satellites bands make it possible to detect changes in reservoirs connected with vegetation processes. The NDVI is very sensitive to emergent, floating plants and algae blooms detection due to NIR band. It can be used for monitoring overall degradation, except it does not facilitate subdivision into overgrowth and algae bloom processes. In compare, the WAVI is sensitive to detection of the emergent and floating plants only, and therefore it facilitates diagnosing overgrowth areas. 
5. The major limitation of using remote sensing data is high cloud density, which significantly reduces the number of observations during most of the year.

\section{REFERENCES}

Alvarez-Mendoza, C. I., Teodoro, A., Ramirez-Cando, L. (2019). Improving NDVI by removing cirrus clouds with optical remote sensing data from Landsat-8-a case study in Quito, Ecuador. Remote Sensing Applications: Society and Environment, 13, 257-274.

Beck, R., Xu, M., Zhan, S., Liu, H., Johansen, R., Tong, S., ... \& Berling, K. (2017). Comparison of satellite reflectance algorithms for estimating phycocyanin values and cyanobacterial total biovolume in a temperate reservoir using coincident hyperspectral aircraft imagery and dense coincident surface observations. Remote Sensing, 9 (6), 538 .

Bogdał, A., Policht-Latawiec, A., Koldras, S. (2015). Changes of Water Quality Indices with Depth at Drinking Water Intake from Dobczyce Reservoir. Annual Set The Environment Protection, 17, 1239-1258.

Dąbrowska, J., Lejcuś, K., Kuśnierz, M., Czamara, A., Kamińska, J., Lejcuś, I. (2016). Phosphate dynamics in the drinking water catchment area of the Dobromierz Reservoir. Desalination and Water Treatment, 57 (53), 25600-25609.

Dąbrowska, J., Pawęska, K., Dąbek, P. B., Stodolak, R. (2017). The implications of economic development, climate change and European water policy on surface water quality threats. Acta Scientiarum Polonorum. Formatio Circumiectus, 16(3), 111.

Dörnhöfer, K., Klinger, P., Heege, T., Oppelt, N. (2018). Multi-sensor satellite and in situ monitoring of phytoplankton development in a eutrophic-mesotrophic lake. Science of The Total Environment, 612, 1200-1214 .

Fuska, J., Kubinský, D., Weis, K., Lackóová, L., Pokrývková, J., Leitmanová, M., Panagopoulos, T. (2017). Area-Storage Capacity Curve of Historic Artificial Water Reservoir Ottergrund, Slovakia-Assessment of the Historical Data With the use of GIS Tools. Journal of Ecological Engineering, 18(1).

Francés, G.E., Quevauviller, P., González, E.S.M., Amelin E.V. (2017). Climate change policy and water resources in the EU and Spain. A closer look into the Water Framework Directive. Environmental Science \& Policy, $69,1-12$.
Gao, Q., Li, Y., Cheng, Q., Yu, M., Hu, B., Wang, Z., Yu, Z. (2016). Analysis and assessment of the nutrients, biochemical indexes and heavy metals in the Three Gorges Reservoir, China, from 2008 to 2013. Water research, 92, 262-274.

González-Márquez, L.C., Torres-Bejarano, F.M., Torregroza-Espinosa, A.C., Hansen-Rodríguez, I.R., Rodríguez-Gallegos, H.B. (2018). Use of LANDSAT 8 images for depth and water quality assessment of El Guájaro reservoir, Colombia. Journal of South American Earth Sciences, 82, 231-238.

Hestir, E.L., Brando, V.E., Bresciani, M., Giardino, C., Matta, E., Villa, P., Dekker, A.G. (2015). Measuring freshwater aquatic ecosystems: The need for a hyperspectral global mapping satellite mission. Remote Sensing of Environment, 167, 181-195.

Huang, S., Huang, Q., Chang, J., Zhu, Y., Leng, G. and Xing, L. (2015). Drought structure based on a nonparametric multivariate standardized drought index across the Yellow River basin, China. Journal of Hydrology, 530, 127-136.

Jaskuła, J., Sojka, M. (2019). Assessment of spectral indices for detection of vegetative overgrowth of reservoirs. Polish Journal of Environmental Studies, 28 (6), [in print).

Jaskuła, J., Sojka, M., Wicher-Dysarz, J. (2018). Analysis of the vegetation process in a two-stage reservoir on the basis of satellite imagery - a case study: Radzyny Reservoir on the Sama River. Annual Set The Environment Protection, 20, 203-220.

Khorrami, Z., Banihashemi, M.A. (2019). Numerical simulation of sedimentation process in reservoirs and development of a non-coupled algorithm to improve long-term modeling. International Journal of Sediment Research, 34 (3), 279-294.

Klein, I., Gessner, U., Dietz, A.J., \& Kuenzer, C. (2017). Global WaterPack-A 250 m resolution dataset revealing the daily dynamics of global inland water bodies. Remote Sensing of Environment, 198, 345-362.

Liu, C., Wu, X., Wang, L. (2019). Analysis on land ecological security change and affect factors using RS and GWR in the Danjiangkou Reservoir area, China. Applied Geography, 105, 1-14.

Martins, V. S., Kaleita, A., Barbosa, C. C., Fassoni-Andrade, A. C., de Lucia Lobo, F., Novo, E. M. (2019). Remote sensing of large reservoir in the drought years: Implications on surface water change and turbidity variability of Sobradinho reservoir (Northeast Brazil). Remote Sensing Applications: Society and Environment, 13, 275-288. 
Noori, R., Berndtsson, R., Adamowski, J.F., Abyaneh, M.R. (2018). Temporal and depth variation of water quality due to thermal stratification in Karkheh Reservoir, Iran. Journal of Hydrology: Regional Studies, 19, 279$-286$.

Pekel, J. F., Cottam, A., Gorelick, N., Belward, A. S. (2016). High-resolution mapping of global surface water and its long-term changes. Nature, 540 (7633), 418.

Przybyła, C., Kozdrój, P., Sojka, M. (2015). Application of Multivariate Statistical Methods in Water Quality Assessment of River-reservoirs Systems (on the Example of Jutrosin and Pakosław Reservoirs, Orla Basin). Annual Set The Environment Protection, 17 (2), 1125-1141.

Silva, T., Giani, A., Figueredo, C., Viana, P., Khac, V.T., Lemaire, B. J., ..., Vinçon-Leite, B. (2016). Comparison of cyanobacteria monitoring methods in a tropical reservoir by in vivo and in situ spectrofluorometry. Ecological Engineering, 97, 79-87.

Sojka, M., Jaskuła, J., Wicher-Dysarz, J., Dysarz, T. (2017). Analysis of selected reservoirs functioning in the Wielkopolska region. Acta Scientiarum Polonorum. Formatio Circumiectus, 16(4), 205.

Sojka, M., Jaskuła, J., Wróżynski, R., Waligórski, B. (2019). Application of Sentinel-2 satellite imagery to assessment of spatio-temporal changes in the reservoir overgrowth process-A case study: Przebedowo, West Poland. Carpathian J. Earth Environ. Sci., 14, 39-50.

Sojka, M., Siepak, M., Jaskuła, J., \& Wicher-Dysarz, J. (2018). Heavy Metal Transport in a River-Reservoir System: a Case Study from Central Poland. Polish Journal of Environmental Studies, 27 (4).

Song, C., Huang, B., Ke, L., Richards, K. S. 2014. Remote sensing of alpine lake water environment changes on the Tibetan Plateau and surroundings: A review. ISPRS Journal of Photogrammetry and Remote Sensing, 92, 26-37.

Souza, M.D.C.D., Crossetti, L.O., Becker, V. (2018). Effects of temperature increase and nutrient enrichment on phytoplankton functional groups in a Brazilian semi-arid reservoir. Acta Limnologica Brasiliensia, 30.

Tadesse, A., Dai, W. (2019). Prediction of sedimentation in reservoirs by combining catchment based model and stream based model with limited data. International journal of sediment research, 34(1), 27-37.
Tang, X., Li, R., Wu, M., Zhao, W., Zhao, L., Zhou, Y., Bowes, M. J. (2019). Influence of turbid flood water release on sediment deposition and phosphorus distribution in the bed sediment of the Three Gorges Reservoir, China. Science of the Total Environment, 657, 36-45.

Wang, K., Shi, H., Chen, J., Li, T. (2019). An improved operation-based reservoir scheme integrated with Variable Infiltration Capacity model for multiyear and multipurpose reservoirs. Journal of Hydrology, 571, 365-375.

Wen, Z., Wu, S., Chen, J., Lü, M. (2017). NDVI indicated long-term interannual changes in vegetation activities and their responses to climatic and anthropogenic factors in the Three Gorges Reservoir Region, China. Science of The Total Environment, 574, 947-959.

Wicher-Dysarz, J. (2019). Analysis of Shear Stress and Stream Power Spatial Distributions for Detection of Operational Problems in the Stare Miasto Reservoir. Water, 11(4), 691.

Xiao, Y., Zhang, J., Cui, T., Gong, J., Liu, R., Chen, X., Liang, X. (2019). Remote sensing estimation of the biomass of floating Ulva prolifera and analysis of the main factors driving the interannual variability of the biomass in the Yellow Sea. Marine pollution bulletin, 140, 330-340 .

Villa, P., Mousivand, A., Bresciani, M. (2014). Aquatic vegetation indices assessment through radiative transfer modeling and linear mixture simulation. International Journal of Applied Earth Observation and Geoinformation, 30, 113-127.

Yadav, S., Yoneda, M., Susaki, J., Tamura, M., Ishikawa, K., Yamashiki, Y. (2017). A satellite-based assessment of the distribution and biomass of submerged aquatic vegetation in the optically shallow basin of Lake Biwa. Remote Sensing, 9 (9), 966.

Yu, M.L., Hong, G. X., Xu, H., Zhu, G. W., Zhu, M.Y., Quan, Q.M. (2019). Effects of Cyanobacterial Blooms in Eutrophic Lakes on Water Quality of Connected Rivers. Huan Jing Ke Xue, Huanjing Kexue, 40(2), 603-613 .

Zhu, J., Wang, X., Zhang, L., Cheng, H., Yang, Z. (2015). System dynamics modeling of the influence of the TN/ TP concentrations in socioeconomic water on NDVI in shallow lakes. Ecological Engineering, 76, 27-35. 


\section{ANALIZA PROCESÓW DEGRADACJI ZACHODZĄCYCH W ZBIORNIKACH RETENCYJNYCH NA PODSTAWIE DANYCH SATELITARNYCH}

\section{ABSTRAKT}

\section{Cel pracy}

Podstawowym celem pracy była ocena zmian czasowo-przestrzennych wegetacji występujących w 12 zbiornikach retencyjnych zlokalizowanych w dorzeczu Odry. Analizę przeprowadzono dla zbiorników o różnych konstrukcjach - jednostopniowych, zbiorników z wydzieloną częścią wstępną oraz lateralnych. Drugim celem pracy była analiza możliwości wykorzystania danych satelitarnych do monitorowania dynamiki procesów wegetacyjnych.

\section{Materiał i metody}

Monitorowanie i mapowanie zmian czasowo-przestrzennych wegetacji zachodzących w zbiornikach analizowano na podstawie danych z satelity Sentinel-2. Analiza procesów degradacji przeprowadzona została przy wykorzystaniu indeksów NDVI i WAVI. W celu określenia zmian przestrzennych, zbiorniki podzielono na strefy równe $250 \mathrm{~m}$. Analiza skupień (CA) została wykorzystana do grupowania zbiorników w klastry na podstawie podobieństw pomiędzy wartościami indeksów spektralnych.

\section{Wyniki i wnioski}

Analiza skupień (CA) wykazała, że każdy ze zbiorników funkcjonuje jako indywidualny obiekt, w którym decydujący wpływ na procesy degradacji może mieć inny czynnik. Zaobserwowano, że dwustopniowa konstrukcja zbiorników wpływa korzystnie na ograniczenie dopływu zanieczyszczeń do części głównej, skupiając procesy degradacji w zbiorniku wstępnym. Ponadto wykazano, że funkcjonowanie zbiorników lateralnych może pozytywnie wpływać na ograniczenie procesów degradacji w obrębie zbiornika. Analiza możliwości wykorzystania zdjęć satelitarnych wykazała, że satelity Sentinel-2 stanowią obiecujące źródło danych umożliwiające detekcję procesów degradacji w ujęciu czasowym i przestrzennym. Głównym ograniczeniem wykorzystania zobrazowań satelitarnych jest pokrycie chmur, które znacznie zmniejsza liczbę obserwacji w ciągu roku.

Słowa kluczowe: zbiorniki retencyjne, Sentinel-2, przezroczystość wody, zarastanie, dane satelitarne 